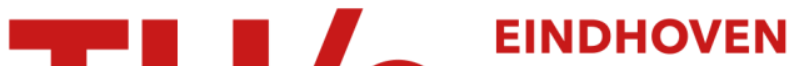 \\ UNIVERSITY OF \\ TECHNOLOGY
}

\section{The mechanism of dimethyl ether formation from methanol catalyzed by zeolitic protons}

\section{Citation for published version (APA):}

Blaszkowski, S. R., \& Santen, van, R. A. (1996). The mechanism of dimethyl ether formation from methanol catalyzed by zeolitic protons. Journal of the American Chemical Society, 118(21), 5152-5153.

https://doi.org/10.1021/ja954323k

DOI:

10.1021/ja954323k

Document status and date:

Published: 01/01/1996

\section{Document Version:}

Publisher's PDF, also known as Version of Record (includes final page, issue and volume numbers)

\section{Please check the document version of this publication:}

- A submitted manuscript is the version of the article upon submission and before peer-review. There can be important differences between the submitted version and the official published version of record. People interested in the research are advised to contact the author for the final version of the publication, or visit the $\mathrm{DOI}$ to the publisher's website.

- The final author version and the galley proof are versions of the publication after peer review.

- The final published version features the final layout of the paper including the volume, issue and page numbers.

Link to publication

\section{General rights}

Copyright and moral rights for the publications made accessible in the public portal are retained by the authors and/or other copyright owners and it is a condition of accessing publications that users recognise and abide by the legal requirements associated with these rights.

- Users may download and print one copy of any publication from the public portal for the purpose of private study or research.

- You may not further distribute the material or use it for any profit-making activity or commercial gain

- You may freely distribute the URL identifying the publication in the public portal.

If the publication is distributed under the terms of Article $25 \mathrm{fa}$ of the Dutch Copyright Act, indicated by the "Taverne" license above, please follow below link for the End User Agreement:

www.tue.nl/taverne

Take down policy

If you believe that this document breaches copyright please contact us at:

openaccess@tue.nl

providing details and we will investigate your claim. 


\section{The Mechanism of Dimethyl Ether Formation from Methanol Catalyzed by Zeolitic Protons}

\author{
Solange R. Blaszkowski* and Rutger A. van Santen
}

\begin{abstract}
Schuit Institute of Catalysis, Laboratory of Inorganic Chemistry and Catalysis/Theory Group Eindhoven University of Technology P.O. Box 513, $5600 \mathrm{MB}$ Eindhoven, The Netherlands
\end{abstract}

Received December 29, 1995

The methanol-to-gasoline (MTG) process ${ }^{1}$ is one of the most successful routes for the catalytic conversion of methanol to hydrocarbons in the gasoline boiling range $\left(30-200{ }^{\circ} \mathrm{C}\right)$. A large variety of different experiments established that methanol catalyzed by an acidic zeolite is first dehydrated to dimethyl ether (DME) $)^{2}$ and that an equilibrium mixture of methanol and DME is then converted to olefins, aliphatics, and aromatics up to $\mathrm{C}_{10}$. The mechanism of methanol adsorption, dehydration, and specially, formation of the first $\mathrm{C}-\mathrm{C}$ bond and the nature of the intermediates involved are still not fully understood. Concerning DME formation, different mechanisms have been proposed in the literature. Bandiera and Naccache ${ }^{3}$ proposed the reaction of methanol occurs at the Brønsted acid and its adjacent Lewis basic sites with formation of the two surface species $\left[\mathrm{CH}_{3} \cdot \mathrm{OH}_{2}\right]^{+}$and $\left[\mathrm{CH}_{3} \mathrm{O}\right]^{-}$which upon condensation give DME and water. Kubelková et al. ${ }^{4}$ proposed that methanol is initially adsorbed at the zeolite. With transference of the zeolitic proton the methoxonium ion, $\mathrm{H}_{3} \mathrm{COH}_{2}{ }^{+}$, is formed. This dehydrates leaving a methyl group bonded to the zeolitic surface. Later on, those surface methoxy groups can react with another methanol molecule to form dimethyl ether. Here we show that two parallel reaction pathways for the production of dimethyl ether are possible. The first path proceeds via two distinct steps, similar to that proposed by Kubelková et al. ${ }^{4}$ The second path, as proposed by Bandiera and Naccache, ${ }^{3}$ involves the simultaneous adsorption and reaction of two methanol molecules with formation of DME and water in one step.

The results presented are based on density functional theory (DFT) calculations, as implemented in the DGauss program. ${ }^{5}$ All discussed structures herein were obtained including nonlocal exchange and correlation corrections due to Becke $^{6}$ and Perdew, ${ }^{7}$ respectively, in a self-consistent manner. We used double-zeta quality basis sets including polarization functions for all nonhydrogen atoms. ${ }^{8}$ A second set of basis functions (A1), the auxiliary basis set, ${ }^{9}$ is used to expand the electron density in a set of single-particle Gaussian-type functions. They were optimized for use in DFT in order to minimize the basis set superposition error, BSSE. ${ }^{10}$ Geometry optimization calculations are carried out to the energy minimum in the case of reactants, adsorption complexes, and products and to a saddle point in the case of transition states (TS). All energies were corrected for zero-point energy, and the corresponding structures presented no (for adsorption complexes) or one (for TS's)

* Author to whom correspondence should be addressed.

(1) (a) Meisel, S. L.; McCullogh, J. P.; Lechthaler, C. H.; Weisz, P. B. CHEMTECH 1976, 6, 86. (b) Chang, C. D. Hydrocarbons from Methanol; Marcel Dekker: New York, 1983.

(2) Spivey, J. J. Chem. Eng. Commun. 1991, 110, 123.

(3) Bandiera, J.; Naccache, C. Appl. Catal. 1991, 69, 139.

(4) Kubelková, L.; Nováková, J.; Nedomová, K. J. Catal. 1990, 124, 441 .

(5) Andzelm, J.; Wimmer, E. J. Chem. Phys. 1992, 96, 1280.

(6) Becke, A. D. Phys. Rev. A 1988, 38, 3098.

(7) Perdew, J .P. Phys. Rev. B 1986, 33, 8822.

(8) Godbout, N.; Andzelm, J.; Wimmer, E.; Salahub, D. R. Can. J. Chem. 1992, 70, 560 .

(9) Andzelm, J.; Russo, N.; Salahub, D. R. Chem. Phys. Lett. 1987, 142, 169. 553.

(10) Radzio, E.; Andzelm, J.; Salahub, D. R. J. Comp. Chem. 1985, 6, imaginary mode. No symmetry constraints have been used in the optimization of any of the studied structures. The clusters $\mathrm{H}_{3} \mathrm{SiOHAl}(\mathrm{OH})_{2} \mathrm{OSiH}_{3}(\mathrm{AlOH})$ and $\mathrm{H}_{3} \mathrm{SiOHAlH}_{2} \mathrm{OSiH}_{3}(\mathrm{AlH})$ were used to represent the acidic zeolite. The AlH cluster was also used in its methoxy form, where the acidic proton was replaced by a methyl $\left(\mathrm{CH}_{3}\right)$ group.

Two different pathways were studied for the DME formation. The first path (Path I) involves two different elementary steps, as shown in Figure 1. The AlH cluster has been used, but the hydride termination of the silicon atoms are not shown in the pictures. The first step is associated with the initial adsorption of one methanol molecule at the zeolite acidic site which is then dehydrated, leaving a methyl group attached to the basic oxygen of the zeolite. This step was discussed earlier in more detail. ${ }^{11}$ The activation barrier taken with respect to the most stable mode of adsorption of one methanol molecule at the acidic site $\left(\mathrm{PI}-\mathrm{ads}_{\mathrm{end}-\mathrm{on}}\right)$ is rather high, $+215 \mathrm{~kJ} / \mathrm{mol} .{ }^{11}$ Using Hartree-Fock plus MP2 correction ${ }^{12}$ this barrier was found to be $+231 \mathrm{~kJ} / \mathrm{mol}$. The methoxonium ion $\left(\mathrm{CH}_{3} \mathrm{OH}_{2}{ }^{+}\right)$, proposed ${ }^{4,13}$ to be a stable intermediate species in the dehydration process, was found to be a transition state $e^{11,12,14}$ for the reaction of hydrogen exchange. The dehydration process is followed by the reaction of the surface methoxy species with a second methanol molecule. The adsorption of the second methanol to the surface methoxy (PI-ads1) is exothermic with an adsorption energy of $-37 \mathrm{~kJ} / \mathrm{mol}$. With respect to this state, the true activation barrier for DME formation (the energy difference between PI-ads1 and PI-ts1) was calculated to be $+160 \mathrm{~kJ} / \mathrm{mol}$. The rate-limiting step for DME formation according to this first pathway is, thus, the dehydration of the first methanol molecule, $+215 \mathrm{~kJ} / \mathrm{mol}$. The $\mathrm{CH}_{3}$ group of the transition state PI-ts1 has characteristics of a carbenium ion with a trigonal planar geometry. It is similar to the TS for the dehydration process, PI-ts ${ }_{\text {dehyd. }}$. For both TS's, the acidic and basic sites of the zeolite are involved.

The reaction energy diagram for the second reaction path of methanol dehydration (Path II) using the $\mathrm{AlOH}$ cluster is shown in Figure 2. In this second path two methanol molecules are coadsorbed in the acidic/basic sites of the zeolite (PII-ads1 in the figure). The heat of adsorption of two methanol molecules at the acidic site is rather strong, $-130 \mathrm{~kJ} / \mathrm{mol}$ (or $-65 \mathrm{~kJ} / \mathrm{mol}$ per methanol molecule). Note that the experimental adsorption energy is given in terms of "kilojoules per mole of methanol". As expected, the last value $(-65 \mathrm{~kJ} / \mathrm{mol})$ is slightly lower than the one calculated earlier ${ }^{11}$ for a single methanol molecule $(-73$ $\mathrm{kJ} / \mathrm{mol}$ for the $\mathrm{AlOH}$ cluster). This result agrees with one of the experimental heats of adsorption for methanol in H-ZSM5 zeolite reported in the literature, $-63 \mathrm{~kJ} / \mathrm{mol},{ }^{15}$ but it is lower than the other, $-115 \mathrm{~kJ} / \mathrm{mol}^{14}$ The adsorption is followed by the rotation of the methyl group of the right-side methanol molecule in such a way that the methyl group is now free to interact with the hydroxyl group of the left-side methanol molecule (PII-ads2). The last is $\approx 55 \mathrm{~kJ} / \mathrm{mol}$ less stable than PII-ads1. Via a rather complex transition state (PII-ts2) water and DME can be directly formed. In the transition state the zeolitic proton is transferred to the right-side methanol, forming a water molecule. The $\mathrm{C}-\mathrm{O}$ bond stretches, and the methyl group is now much closer to the left-side methanol. The central methyl group assumes sp2 hybridization, characteristic of a

(11) Blaszkowski, S. R.; van Santen, R. A. J. Phys. Chem. 1995, 99, 11728 .

(12) Zocovich-Wilson, C. M.; Viruela, P.; Corma, A. J. Phys. Chem. 1995, 99, 13224.

(13) (a) Mirth, G.; Lercher, J. A.; Anderson, M. W.; Klinowski, J. J. Chem. Soc. Faraday Trans. 1990, 86, 3039. (b) Mirth, G.; Kogelbauer, A.; Lercher, J. A. In Proceedings of the 7th International Zeolite Conference, Montreal, 1992; von Ballamos, R., Higgins, J. B., Treacy, M. M. J., Eds.; Butterworths: London, 1993; p 251.

(14) Sauer, J.; Ugliengo, P.; Garrone, E.; Saunders, V. R. Chem. Rev. 1994, 94, 2095.

(15) Messow U.; Quitzsch, K.; Herden, H. Zeolites 1984, 4, 255. 

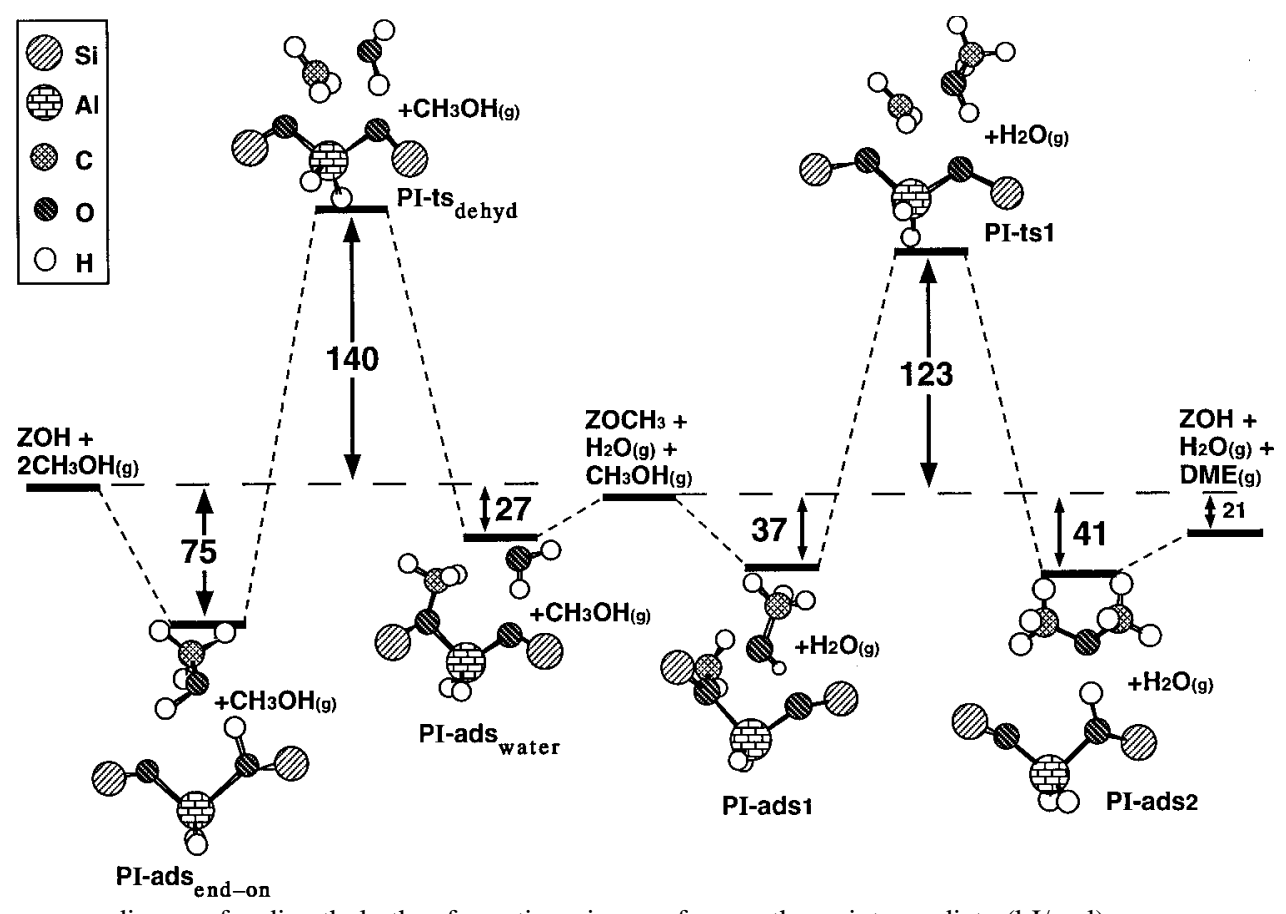

Figure 1. Reaction energy diagram for dimethyl ether formation via a surface methoxy intermediate (kJ/mol).

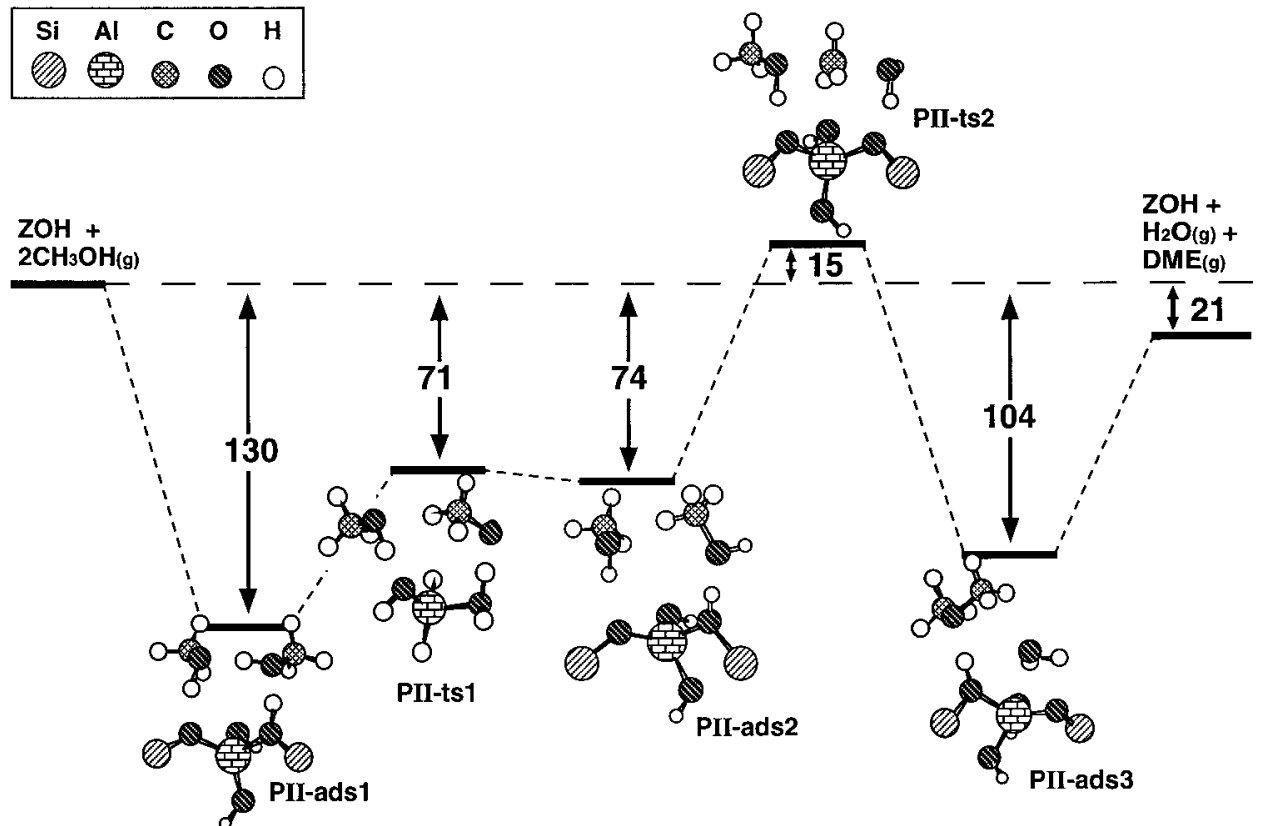

Figure 2. Reaction energy diagram for methanol dehydration to dimethyl ether via an associative mechanism (kJ/mol).

carbenium ion. The proton of the second methanol molecule is transferred back to the zeolite regenerating the acidic site, and simultaneously, DME is formed. In the resulting adsorption complex (PII-ads3) water and DME are strongly adsorbed to the acidic site. Nearly $80 \mathrm{~kJ} / \mathrm{mol}$ is necessary to desorb them. As it can be seen in the figure, the activation barrier with respect to the reactants is very low, only $+15 \mathrm{~kJ} / \mathrm{mol}$. With respect to the adsorption complex of the two methanol molecules (PIIads1), the true activation barrier for this path becomes +145 $\mathrm{kJ} / \mathrm{mol}$. This should be compared to the experimental true activation barrier ${ }^{3}$ for methanol dehydration to DME for dealuminated $\mathrm{H}$-mordenite, reported to be $+80 \mathrm{~kJ} / \mathrm{mol}$. The experimental barrier ${ }^{3}$ is rather low and not consistent with one of the heat of adsorption for methanol reported in the literature, $-115 \mathrm{~kJ} / \mathrm{mol}^{14}$ With respect to the mechanism proposed by Bandiera and Naccache, ${ }^{3}$ although the general idea is the same as for Path II, the details of the mechanism are different. In between the intermediates proposed $\mathrm{CH}_{3} \mathrm{OH}_{2}{ }^{+}$and $\mathrm{CH}_{3} \mathrm{O}^{-}$, the first is a TS ${ }^{11,12,14}$ and the second was not obtained in the cal- culations. In the Path II we propose that two methanol molecules adsorb at the Lewis basic and Brønsted acid sites, which then undergo the reaction via a complex carbenium-like TS.

The activation barrier obtained for Path II is $70 \mathrm{~kJ} / \mathrm{mol}$ lower than the limiting step found for the other pathway involving the intermediate surface methoxy species $(+215 \mathrm{~kJ} / \mathrm{mol})$. Thus, Path II will have preference over Path I. One concludes that DME is formed according to an associative mechanism without formation of an intermediate methoxy species. The reaction mechanism is of the $\mathrm{S}_{\mathrm{N}} 2$ (backside) ${ }^{16}$ type, similar as expected in the homogeneous phase.

Acknowledgment. S.R.B. thanks CNPq (Brazil) for a scholarship. Computational resources were supplied by NCF (the Netherlands) under project SC-417.

\section{JA954323K}

(16) Basic Principles of Organic Chemistry, 2nd ed.; Roberts, J. D., Caserio, M. C., Eds.; W. A. Benjamin, Inc.: Menlo Park, 1981; p 219. 